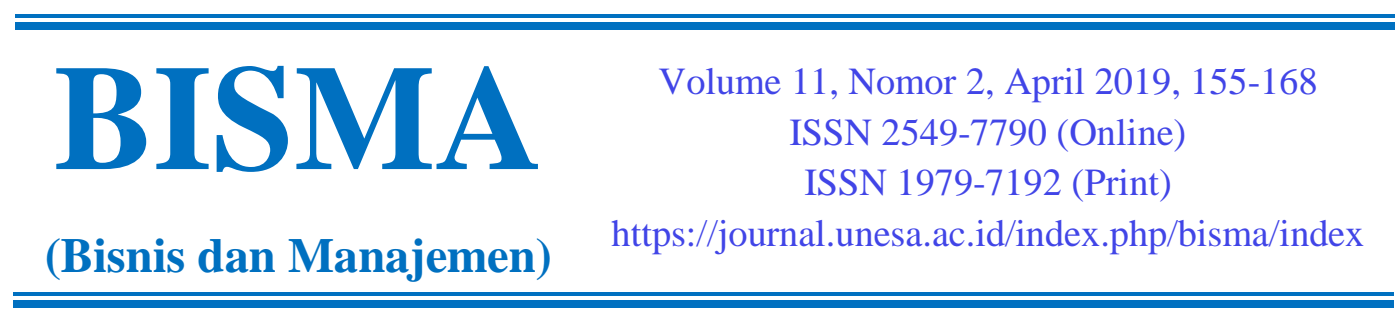

\title{
Efektivitas Bisnis Berbasis Teknologi Internet dalam Membangun Kinerja Kewirausahaan
}

\author{
Mohamad Nur Utomo ${ }^{1}$ \\ Fakultas Ekonomi, Universitas Borneo Tarakan ${ }^{1}$ \\ Email korespondensi: mohnurutomo@gmail.com
}

\begin{abstract}
Entrepreneurial success will have an impact on economic growth. Entrepreneurship that integrates internet technology in its business activities will be able to improve business performance in the current digital economy era. This study aims to empirically examine the effect of internet technology-based business implementation on business performance. Internet technology-based business applications are measured by 5 indicators (online communication channels, online promotion channels, online supplier distribution channels, online sales channels, and online transaction channels). While business performance is measured by 5 indicators (profit growth, sales growth, capital growth, efficiency and customer growth). The sample in this study were 100 UMKM in Tarakan city using the sample area probability sample method based on the sub-district area. Data analysis technique uses PLS-SEM method with WarpPls 6.0 application. The results showed that internet technology-based business implementation was able to encourage business performance improvement. Entrepreneur must be able to integrate its business operations with Internet-based technologies to create opportunities and facilitate building performance.
\end{abstract}

Keywords: business performance, entrepreneurship, internet technology, online business, SMES

Received: 25 Desember 2018

Reviewed: 17 Januari 2019

Accepted: 8 February 2019

Published: 23 April 2019

\section{PENDAhuluan}

Perkembangan teknologi mengubah lanskap ekonomi dan mempengaruhi dinamika lingkungan bisnis. Seiring dengan globalisasi UMKM menghadapi lingkungan bisnis yang semakin kompetitif mengakibatkan kesulitan untuk meningkatkan atau mempertahankan kinerja bisnis (Kraus et al., 2012). Sebagian 
dari literatur menyatakan bahwa faktor penentu kewirausahaan yang sukses salah satunya adalah berfokus pada teknologi. Maka UMKM atau wirausaha harus mampu melihat perubahan kebiasaan dan gaya hidup manusia yang akan mempengaruhi strategi bisnis yang mereka jalankan. Pada era digital saat ini berinteraksi dengan teknologi internet merupakan gaya hidup dan menjadi kebiasaan aktivitas manusia sehari-hari. Berikut data yang menggambarkan fenomena internet menjadi bagian gaya hidup manusia yang ditunjukkan dengan peningkatan penggunaan internet di Indonesia dalam Gambar 1.

Berdasarkan Gambar 1 dari hasil survey Asosiasi Penyelenggara Jasa Internet Indonesia (APJII) menunjukkan penggunaan internet di Indonesia mengalami peningkatan yang signifikan dalam beberapa tahun (2005-2014), kemudian hingga tahun 2016 menunjukkan 51,8\% penduduk indonesia merupakan pengguna internet (APJII, 2016). Selain itu berdasarkan laporan kinerja Kementerian Komunikasi dan Informatika menunjukkan bahwa penetrasi seluler pada indonesia tahun 2016 mencapai 126\% (Kemkominfo, 2016). Dari data fenomena tersebut menunjukkan penggunaan teknologi internet dan seluler di Indonesia yang semakin tinggi dan menjadi gaya hidup akan mengubah cara wirausaha dalam menjalankan bisnisnya. Teknologi internet memungkinkan bisnis untuk mengotomatiskan operasi manual dan memproses informasi lebih cepat.

Teknologi internet sering dianggap secara fundamental mengubah paradigma bisnis dan semakin terintegrasi ke dalam fungsi pemasaran dalam sebuah usaha (Prasad et al., 2001). Internet marketing telah muncul sebagai kekuatan pendorong perubahan dalam perusahaan dalam hubungan dengan pelanggan (Strauss et al., 2003). Maka wirausaha harus dapat mengintegrasikan kompetensi dan teknologi berbasis internet dalam menjalankan bisnisnya. Hasil riset Rosalind Jones et al. (2015) menunjukkan UMKM yang bergerak bidang pariwisata di Inggris yang antusias beradaptasi dan belajar memanfaatkan sepenuhnya pemasaran digital memperoleh manfaat meningkatkan peluang untuk berinovasi pada skala yang belum pernah terjadi sebelumnya misalnya: dalam mendefinisikan target pasar, karena pemasaran digital menawarkan akses informasi yang tak tertandingi. Beberapa penelitian lainnya telah menunjukkan keefektivan media internet sebagai media pemasaran UMKM (Chaston dan Mangles, 2003; Datta dan R, 2005; Mujiyana et al., 2012; Reimers et al., 2016). Dengan demikian akan semakin membuka peluang dan memudahkan wirausaha atau UMKM dalam melakukan promosi dan mengembangkan usaha melalui media internet. 


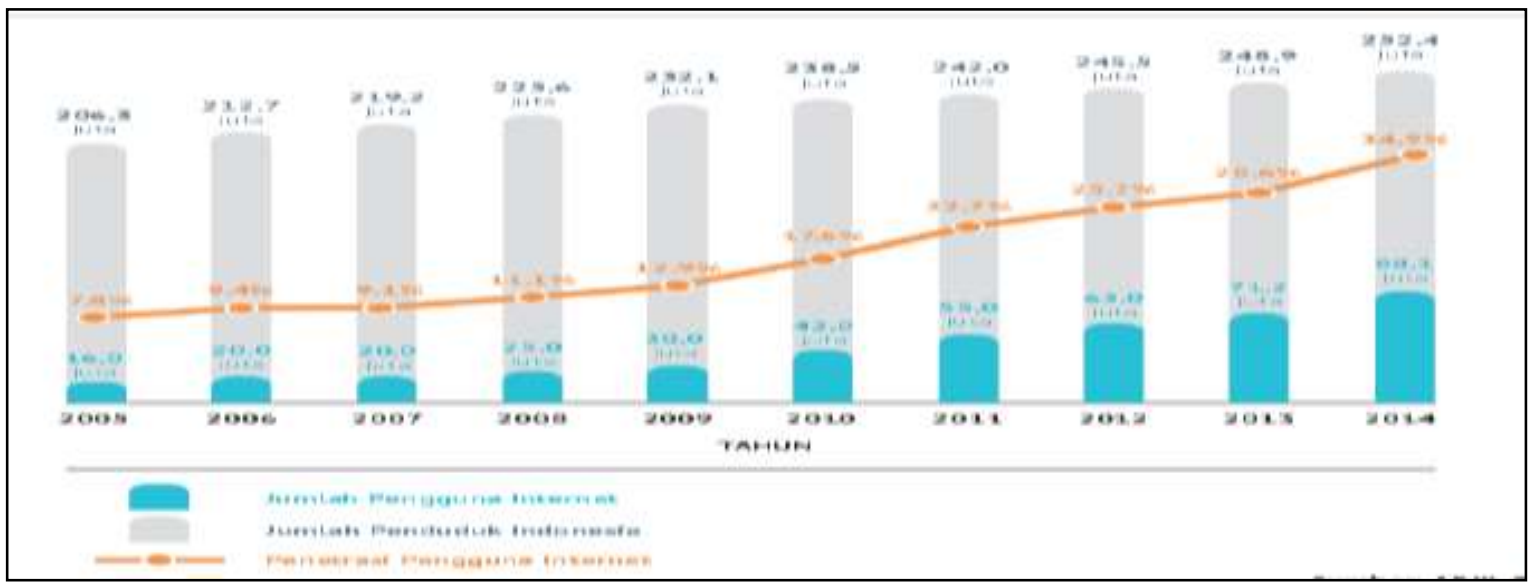

Sumber: APJII, 2016

Gambar 1. Perkembangan Penggunaan Internet di Indonesia

Penelitian ini bertujuan menguji secara empiris penerapan bisnis berbasis teknologi internet dalam membangun kinerja usaha. Penelitian dilakukan khususnya pada UMKM di kota Tarakan. Kota Tarakan sebagai kotamadya dengan struktur perekonomian yang didominasi oleh sektor perdagangan. Sesuai data pada tahun 2016 memiliki jumlah penduduk sebesar 244.190 jiwa dan tingkat Produk Domestik Regional Bruto (PDRB) sebesar 24,12 triliun rupiah di mana kontribusi tertinggi yaitu 20,72\% disumbang oleh sektor perdagangan besar dan eceran, reparasi sepeda motor dan mobil (BPS-Tarakan, 2017). Pertumbuhan Usaha Mikro Kecil Menengah (UMKM) di prediksi meningkat setiap tahunnya, pada tahun 2016, jumlah perusahaan kecil dan menengah di Kota Tarakan adalah 530 perusahaan dengan jumlah tenaga kerja sebanyak 2.271orang (BPS-Tarakan, 2017). Bila dilihat berdasarkan klasifikasi industri, dari 530 perusahaan kecil dan menengah terdiri dari 9,62 persen untuk sektor sandang; 6,98 persen sektor mebel; 18,49 persen sektor pangan; 13,02 persen sektor kimia dan bahan bangunan; 6,04 persen sektor hasil hutan; dan 41,70 persen sektor logam. Untuk lebih jelasnya klasfikasi industri kecil dan menengah kota Tarakan dapat ditunjukkan dalam Gambar 2 berikut. 


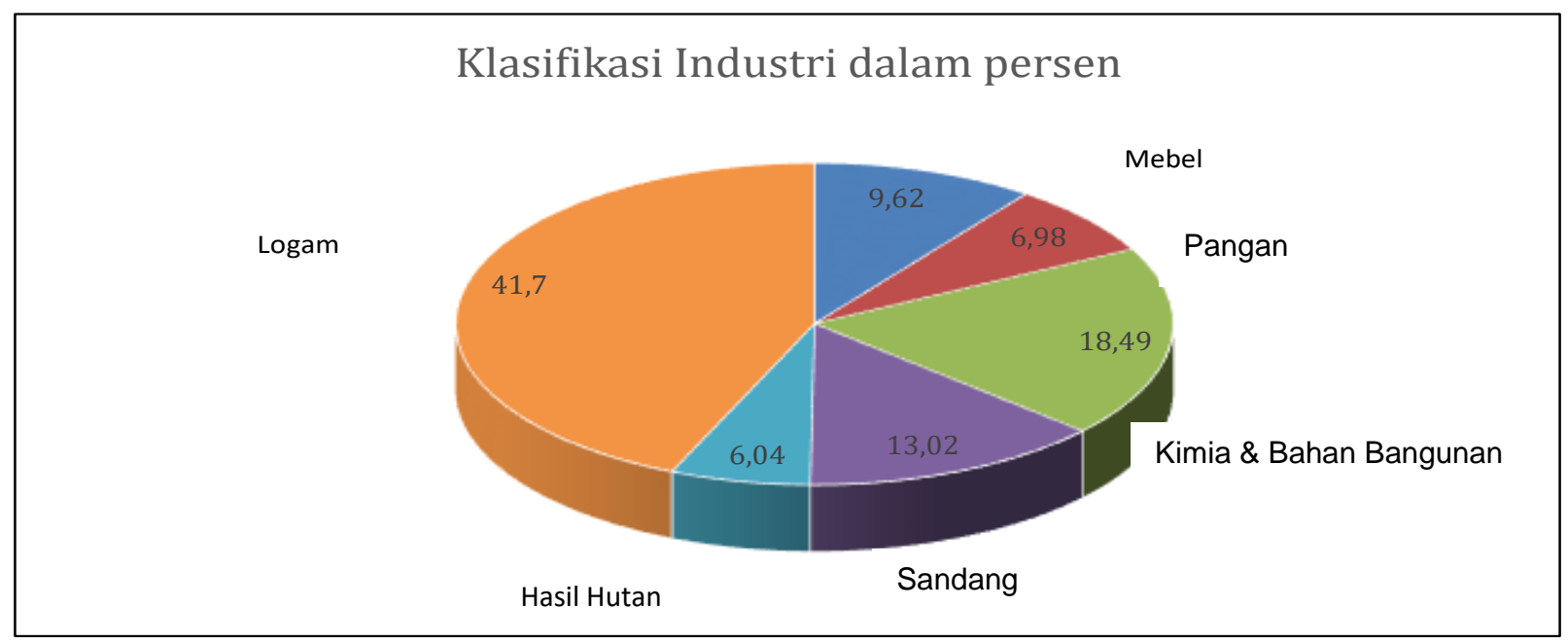

Sumber: BPS-Tarakan (2017)

Gambar 2. Klasifikasi Industri Kecil dan Menengah Kota Tarakan

Berdasarkan data-data kota Tarakan yang diuraikan sebelumnya menjadi menarik untuk diteliti apakah UMKM dikota Tarakan dalam menjalankan strategi bisnisnya terutama dalam era digital ekonomi memanfaatkan teknologi internet untuk memfasilitasi operasional bisnisnya (promosi, penjualan, transaksi dan aktivitas lainnya) dalam membangun kinerja. Hasil penelitian menunjukkan bahwa penerapan bisnis berbasis teknologi internet berpengaruh positif terhadap kinerja usaha pada UMKM dikota Tarakan. Penulisan paper ini terdiri dari enam bagian. Bagian pertama pendahuluan. Bagian selanjutnya memberikan metodologi penelitian. Bagian ke tiga menyajikan hasil empiris. Bagian empat memberikan kesimpulan. Bagian kelima pembahasan dan bagian terakhir keterbatasan penelitian.

\section{Bisnis Berbasis Teknologi Internet}

Internet sering digambarkan sebagai salah satu penemuan teknologi paling transformasi sejak Revolusi Industri (The-Economist, 1999). Beberapa komentator percaya bahwa internet secara mendasar dapat mengubah paradigma bisnis, berpotensi memengaruhi setiap tautan dalam rantai nilai perusahaan (Papows, 1998). Berbagai sarana internet tools yang dapat digunakan dalam kegiatan bisnis seperti website, blog, sosial media dan sifatnya yang global, real time dan praktis membuat kegiatan promosi usaha akan lebih maksimal karena jangkauannya yang luas dan hampir tidak terbatas. Internet dapat mempercepat pertukaran informasi secara realtime dan memungkinkan perbaikan di seluruh rantai industri atau setiap perusahaan.

Teknologi internet mempengaruhi baik dalam kegiatan operasional bisnis dan pemasaran pada konsumen melalui tiga jenis salauran pemasaran: (1) saluran komunikasi, yang fungsi utamanya adalah memberi tahu pembeli dan calon pembeli 
tentang ketersediaan produk / layanan dan atribut penjual yang memungkinkan pembeli dan calon pembeli untuk berkomunikasi dengan penjual; (2) saluran transaksi, yang fungsi utamanya adalah memfasilitasi pertukaran ekonomi antara pembeli dan penjual; dan (3) saluran distribusi, yang fungsi utamanya adalah memfasilitasi pertukaran fisik (Peterson et al., 1997). Dengan menggunakan media Internet, pemasaran akan lebih langsung menuju calon konsumen atau pelanggan yang dituju. Para calon konsumen/calon pelanggan bisa mendapatkan informasi lebih dengan menggunakan Internet dibandingkan menggunakan media elektronik atau cetak lainnya.

\section{Kinerja Usaha}

Pentingnya kinerja usaha sebagai tujuan efektivitas organisasi, dalam konsep yang lebih luas, ada dua indikator yang menjelaskan kinerja usaha termasuk kinerja keuangan (pertumbuhan penjualan, profitabilitas, penghasilan per saham) dan kinerja operasional (pangsa pasar, produk baru, kualitas produk, efektivitas pemasaran dan nilai tambah) (Venkatraman dan Ramanujam, 1986). Selanjutnya kinerja perusahaan dalam sebuah penelitian dapat didefinisikan sebagai indikator profitabilitas yang tinggi dan pertumbuhan pangsa pasar di mana pertumbuhan di mana kedua indikator pengukuran tersebut merupakan bagian yag esensial dari kinerja perusahaan dan digunakan untuk mengevaluasi daya saing perusahaan (Soininen et al., 2012).

Pada studi lain indikator kinerja usaha dieksplorasi sebagai pertumbuhan penjualan, pertumbuhan pelanggan, pertumbuhan laba dan pertumbuhan modal kerja (Meutiaa dan Ismail, 2012). Sementara itu pada literatur lain kinerja dibagi menjadi kinerja keuangan dan non-keuangan, di mana kinerja keuangan adalah efisiensi keuangan dan ukuran laba sedangkan kinerja non-keuangan mencakup kepuasan pelanggan, pertumbuhan penjualan, pertumbuhan karyawan dan pangsa pasar (Sidik, 2012 ).

\section{Pengaruh Penerapan Bisnis Berbasis Teknologi Internet terhadap Kinerja Usaha}

Penerapan teknologi internet (seperti situs web, email, blog dan media sosial online) dalam bisnis memungkinkan pengusaha kecil dapat mengubah cara berkomunikasi dengan pelanggan, memasarkan produk dan jasa serta saling berinteraksi dengan pelanggan yang bertujuan untuk membangun hubungan lebih baik. Pendekatan-pendekatan yang dapat dilakukan melalui media internet mendatangkan keuntungan tersendiri bagi wirausaha yang melakukannya, baik dari peningkatan segi penjualan, minat dan perhatian khalayak, referensi untuk selalu berinovasi dan lain sebagainya. 
Beberapa kajian empirik yang menjelaskan pengaruh positif penerapan bisnis berbasis teknologi internet terhadap kinerja usaha diuraikan sebagai berikut. Wade et al. (2004) melakukan studi yang mengeksplorasi pengaruh pasca-adopsi Internet Business Solution (IBS) pada penciptaan nilai bisnis. Di mana nilai bisnis diukur dengan pendapatan perusahaan, biaya langsung dan tidak langsung, dan kepuasan investasi. Penelitian menggunakan sampel 254 UMKM di Kanada dan Amerika Serikat. Hasil penelitian ini menunjukkan bahwa nilai bisnis dapat secara signifikan ditingkatkan dengan menerapkan Internet Business Solution (IBS). Kemudian penelitian lainnya yang dilakukan oleh McGowan dan Durkin (2010) menyatakan secara umum alasan utama wirausaha atau UMKM mengadopsi dan menerapkan internet dalam bisnisnya adalah untuk pengumpulan informasi yang lebih cepat dan menyadari bahwa pentingnya internet dalam mendorong kinerja bisnis.

Doherty et al. (2016) dalam penelitiannya yang menggunakan metode kualitatif menjelaskan isu mendasar dalam kegiatan bisnis UMKM di Irlandia. Penelitian ini mengeksplorasi bagaimana penerimaan teknologi internet dan dampaknya, sehingga membutuhkan pemahaman dan penyelidikan lebih lanjut tentang bagaimana teknologi internet baru diadopsi. Pengadopsian UMKM dan penggunaan teknologi broadband internet mendorong efisiensi dan perkembangan strategis sehari-hari. Penelitian menunjukkan bahwa manajer pemilik UMKM adalah pengambil keputusan utama dan menunjukkan bahwa dengan penggunaan teknologi broadband internet (melalui penggunaan situs web, email, dan media sosial) citra bisnis mereka meningkat dengan lebih baik. Dampak lebih luas dengan berdagang secara online melalui e-commerce membuka pasar internasional baru bagi UKM. Beberapa UMKM dalam menerapkan teknologi broadband internet mungkin menggunakan pendekatan secara bertahap, tetapi bagi UMKM yang lain teknologi ini dapat membuka kemungkinan dengan segera mengalami efisiensi dan meningkatkan produktivitas melalui komunikasi yang efisien atau secara real time.

H1: Penerapan bisnis berbasis teknologi internet dapat meningkatkan kinerja usaha.

\section{METODE PENELITIAN}

Penelitian ini bersifat kausalitas yang bertujuan menguji secara empiris hubungan bisnis berbasis teknologi internet dan kinerja usaha. Penelitian ini di laksanakan di kota Tarakan provinsi Kalimantan Utara, penelitian ditujukan pada UMKM di kota Tarakan.

\section{Sampel Penelitian}

Populasi dalam penelitian ini adalah seluruh UMKM yang ada di kota Tarakan. Sampel dalam penelitian ditentukan berdasarkan wilayah (area probability sample), di mana sampel ditentukan berdasarkan wilayah kecamatan yaitu kecamatan Tarakan 
Tengah, Tarakan Barat, Tarakan Timur dan Tarakan Utara. Teknik pengumpulan data menggunakan metode pengumpulan data primer melalui cara penyebaran kuesioner, untuk keperluan analisis data. Sumber data berasal dari kuesioner yang diisi oleh responden (wirausaha/UMKM). Sampel penelitian adalah para wirausaha UMKM menurut pengertian UU Nomor 20 Tahun 2008 dan pengertian BPS. Berdasarkan hasil pengumpulan data, jumlah sampel penelitian sebanyak 100 responden.

\section{Variabel Penelitian dan Indikator Penelitian}

Dalam penelitian ini ada 2 variabel laten yang diamati dan diukur yaitu bisnis berbasis teknologi internet sebagai variabel independen dan variabel kinerja usaha sebagai variabel dependen. Variabel dalam penelitian ini merupakan variabel laten / unobserved (tidak terukur) yang diproksikan menggunakan persepsi para responden dari indikator-indikator yang ditentukan. Penjelasan variabel penelitian dan indikator penelitian diuraikan dalam tabel 1 .

\section{Teknik Analisis Data}

Penelitian ini dianalisis dengan metode Regresi Linear dengan menggunakan aplikasi SPSS. Untuk menguji hipotesis maka dibuat persamaan model sebagai berikut:

$$
\mathrm{KU}=\alpha+\beta \mathrm{BTI}+\epsilon
$$

Di mana, $\mathrm{KU}=$ Kinerja Usaha, $\mathrm{BTI}=$ Bisnis Berbasis Teknologi Internet

Tabel 1. Variabel Penelitian dan Indikator Penelitian

\begin{tabular}{|c|c|c|c|}
\hline NO & Variabel Laten & Indikator Variabel & $\begin{array}{c}\text { Sumber } \\
\text { Acuan }\end{array}$ \\
\hline 1. & $\begin{array}{l}\text { Bisnis Berbasis Teknologi } \\
\text { Internet } \\
\text { (Independen) }\end{array}$ & $\begin{array}{ll}\text { 1. } & \text { Saluran komunikasi online } \\
\text { 2. } & \text { Saluran promosi online } \\
\text { 3. } & \text { Saluran distribusi pemasok online } \\
\text { 4. } & \text { Saluran Penjualan online } \\
5 . & \text { Saluran Transaksi online } \\
\end{array}$ & $\begin{array}{l}\text { (Peterson et } \\
\text { al., 1997) }\end{array}$ \\
\hline & $\begin{array}{l}\text { Kinerja Usaha } \\
\text { (Dependen) }\end{array}$ & $\begin{array}{ll}\text { 1. } & \text { Pertumbuhan keuntungan } \\
\text { 2. } & \text { Pertumbuhan penjualan } \\
\text { 3. } & \text { Pertumbuhan Modal } \\
\text { 4. } & \text { Efisiensi } \\
\text { 5. } & \text { Pertumbuhan Pelanggan } \\
\end{array}$ & $\begin{array}{l}\text { (Meutiaa dan } \\
\text { Ismail, 2012; } \\
\text { Sidik, 2012) }\end{array}$ \\
\hline
\end{tabular}

Sumber: Teori dan studi empiris yang dikembangkan untuk penelitian ini 


\section{HASIL DAN PEMBAHASAN}

\section{Statistik Deskriptif}

Untuk mengetahui persepsi responden tentang variabel yang diteliti, penelitian ini menggunakan kriteria rentang sebesar $\left[\frac{5-1}{3}\right]=1,33$ sehingga interpretasi nilai menurut Sugiyono (2012) adalah sebagai berikut:

$$
\begin{aligned}
& 1,00-2,33=\text { Rendah } \\
& 2,34-3,66=\text { Sedang } \\
& 3,67-5,00=\text { Tinggi }
\end{aligned}
$$

\section{Bisnis Berbasis Teknologi Internet}

Variabel bisnis berbasis teknologi internet diukur dengan 5 indikator. Berdasarkan hasil survey dan analisis deskriptif, indeks variabel bisnis berbasis teknologi internet disajikan pada Tabel 2. Tabel 2 menunjukkan bahwa rata-rata keseluruhan jawaban responden untuk variabel bisnis berbasis teknologi internet adalah sebesar 3,75. Secara rinci, jawaban responden terkait indikator bisnis berbasis teknologi internet yang tertinggi adalah saluran komunikasi online yaitu sebesar 4,17. Sedangkan indikator bisnis berbasis teknologi internet yang memiliki nilai terendah adalah saluran transaksi online yaitu sebesar 3,2. Hasil interpretasi nilai dari seluruh indikator menunjukkan bisnis berbasis teknologi internet responden memiliki kriteria yang tinggi, artinya penggunaan teknologi internet dalam kegiatan bisnis sudah menjadi menjadi gaya hidup dan mempengaruhi cara wirausaha dalam menjalankan bisnisnya. Teknologi internet memungkinkan bisnis untuk mengotomatiskan operasi manual dan memproses informasi lebih cepat.

\section{Kinerja Usaha}

Variabel kinerja usaha diukur dengan 5 indikator. Berdasarkan hasil survey dan analisis deskriptif, indeks variabel kinerja usaha disajikan pada Tabel 2. Tabel 2 menunjukkan bahwa rata-rata keseluruhan jawaban responden untuk variabel kinerja usaha adalah sebesar 3,78. Secara rinci, jawaban responden terkait indikator kinerja usaha yang tertinggi adalah pertumbuhan pelanggan yaitu sebesar 3,96. Sedangkan indikator kinerja usaha yang memiliki nilai terendah adalah efisiensi yaitu sebesar 3,46. Hasil interpretasi nilai dari seluruh indikator menunjukkan kinerja usaha responden memiliki kriteria yang tinggi, artinya kinerja usaha UMKM mengalami pertumbuhan yang baik untuk keuntungan, penjualan dan modal. 
Tabel 2. Statistik Deskriptif Variabel Bisnis Berbasis Teknologi Internet dan Variabel Kinerja Usaha

\begin{tabular}{llcc}
\hline No & \multicolumn{1}{c}{ INDIKATOR } & Nilai Rata-rata & Kriteria \\
\hline \hline Variabel Bisnis Berbasis Teknologi Internet & & tinggi \\
\hline 1. & Saluran komunikasi online & 4.17 & tinggi \\
\hline 2. & Saluran promosi online & 4.05 & tinggi \\
\hline 3. & Saluran distribusi pemasok online & 3.74 & sedang \\
\hline 4. & Saluran Penjualan online & 3.58 & sedang \\
\hline 5. & Saluran Transaksi online & 3.2 & tinggi \\
\hline & Rata-rata keseluruhan & 3,75 & tinggi \\
\hline Variabel Kinerja Usaha & & tinggi \\
\hline 1. & Pertumbuhan keuntungan & 3.87 & tinggi \\
\hline 2. & Pertumbuhan penjualan & 3.9 & sedang \\
\hline 3. & Pertumbuhan Modal & 3.72 & sedang \\
\hline 4. & Efisiensi & 3.46 & tinggi \\
\hline 5. & Pertumbuhan Pelanggan & 3.96 & \\
\hline & Rata-rata keseluruhan & 3.78 & \\
\hline Sut
\end{tabular}

Sumber: Data primer diolah (2018)

\section{Analisis Regresi Linear}

Analisis Data dengan metode regresi linear meliputi beberapa pengujian yaitu uji validitas dan realibilitas, uji asumsi klasik dan uji statistik t. Seluruh pengujian menggunakan aplikasi SPSS

\section{Uji Validitas dan Reliabilitas}

Uji validitas dan reliabilitas bertujuan untuk menilai validitas dan realibilitas dari indikator-indikator pembentuk variabel laten dalam penelitian ini. Pengujian validitas dalam penelitian ini menggunakan uji korelasi bivariate pearson antara masing-masing skor indikator dengan total skor konstruk. Untuk menguji apalah masing-masing indikator dari suatu variabel valid atau tidak dengan melihat korelasi masing-masing skor indiaktor dengan total skor variabel memiliki korelasi yang signifikan atau tidak. Jika korelasi antar skor indikator dengan total skor konstruk menunjukkan signifikan maka dapat dinyatakan indikator tersebut valid (Ghozali, 2009). Uji korelasi bivariate pearson indikator dari variabel Bisnis Berbasis Teknologi Internet disajikan pada lampiran.

Berdasarkan output terlihat bahwa korelasi antar masing-masing indikator (BTI1, BTI2, BTI3, BTI4, BTI5) terhadap total skor variabel Bisnis Berbasis Teknologi Internet menunjukkan hasil yang signifikan. Uji korelasi bivariate pearson indikator dari variabel Kinerja Usaha terlihat bahwa korelasi antar masing-masing 
indikator (KU1, KU2, KU3, KU4, KU5) terhadap total skor variabel Kinerja Usaha menunjukkan hasil yang signifikan. Sehingga masing-masing indikator untuk Bisnis Berbasis Teknilogi Internet dan Kinerja Usaha terbukti valid.

Uji reliabilitas dalam penelitian ini menggunakan nilai Cronbach di mana kriteria reliabel jika nilai Alpha $<60 \%$ hal ini mengindikasikan ada beberapa responden yang menjawab tidak konsisten kuisoner dari indikator-indikator variabel sehingga harus dibuang dari analisis (Nunnaly, 1967). Nilai Cronbach dari variabel Bisnis Berbasis Teknologi Internet dan variabel kinerja usaha disajikan pada Tabel 6 pada lampiran. Berdasarkan variabel Bisnis Berbasis Teknologi Internet menghasilkan nilai Cronbach Alpha 0,841 atau 84,1\% (>60\%) sehingga dapat disimpulkan bahwa variabel Bisnis Berbasis Teknologi Internet cukup reliable. Demikian juga dengan variabel Kinerja Usaha menghasilkan nilai Cronbach Alpha 0,888 atau $88,8 \%$ (>60\%) sehingga dapat disimpulkan bahwa variabel Kinerja Usaha cukup reliable.

\section{Uji Asumsi Klasik}

Uji asumsi klasik dalam penelitian ini meliputi uji heteroskesdastisitas dan uji normalitas. Uji heteroskesdastisitas dalam penelitian ini menggunakan cara melihat grafik Plot antara nilai prediksi variabel terikat (dependen) yaitu ZPRED dengan residualnya SRESID. Grafik scatter plot disajikan pada Gambar 3.

Berdasarkan grafik scatterplots terlihat bahwa titik-titik menyebar secara acak serta tersebar baik di atas maupun di bawah angka 0 pada sumbu Y. Artinya, tidak terjadi heteroskedastisitas pada model regresi, sehingga model regresi layak dipakai untuk memprediksi. Selanjutnya uji normalitas menggunakan uji KolmogorovSmirnov (K-S). Uji normalitas bertujuan menguji apakah dalam model regresi, variabel pengganggu (residual) memiliki distribusi normal. Pengujiannya mengacu pada nilai Kolmogorov-Smirnov, jika nilai K-S tidak signifikan $(>0,05)$ maka data residual terdistribusi normal (Ghozali, 2009). Hasil uji K-S menghasilkan nilai Kolmogorov-Smirnov sebesar 1,172 dan tidak signifikan pada 0,128 (>0,05). Maka dapat dinyatakan data residual terdistribusi secara normal. 


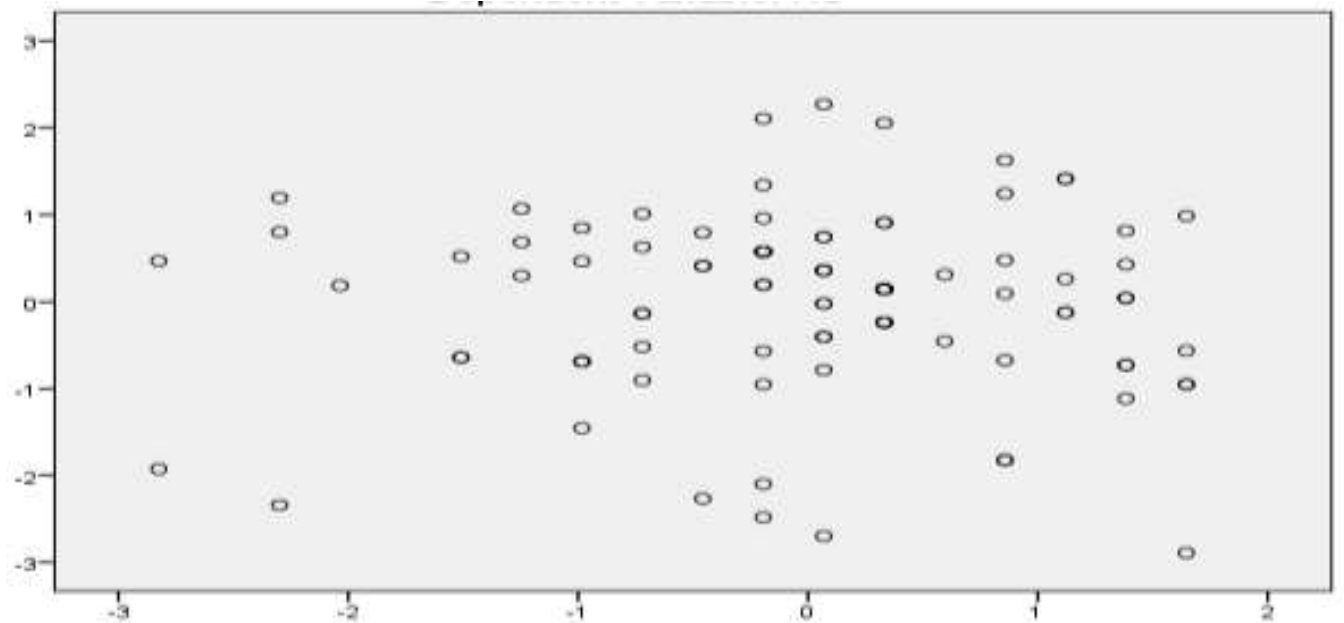

Sumber: data diolah

Gambar 3. Grafik Scatterplot

Tabel 3. Uji Statistik t

\begin{tabular}{lcccc}
\hline \multirow{2}{*}{ Model } & \multicolumn{2}{c}{ Unstandardized Coefficients } & t & Sig. \\
\cline { 2 - 5 } & B & Std. Error & & \\
\hline (Constant) & 8.296 & 1.328 & 6.246 & 0.000 \\
\hline Bisnis Berbasis Internet & 0.566 & 0.069 & 8.153 & 0.000 \\
\hline
\end{tabular}

Sumber: Data Primer di olah

\section{Uji Statistik t}

Uji statistik t menunjukkan seberapa jauh pengaruh satu variabel independen dalam menerangkan variasi variabel dependen. Uji t digunakan untuk menjawab hipotesis dalam penelitian ini. Hasil uji t dapat di sajikan pada Tabel 3. Berdasarkan output pada Tabel 3 menunjukkan bahwa variabel Bisnis Berbasis Teknologi Internet berpengaruh positif signifikan terhadap Kinerja Usaha. Variabel Bisnis Berbasis Teknologi Internet menghasilkan t hitung sebesar 8,153 dengan nilai koefisiennya sebesar 0,566 dan signifikan pada level dibawah $1 \%(<0,01)$.

Hipotesis penelitian ini menyatakan bahwa penerapan bisnis berbasis teknologi internet dapat meningkatkan kinerja usaha. Hasil analisis menunjukkan bahwa variabel Bisnis Berbasis Teknologi Internet berpengaruh positif signifikan terhadap Kinerja Usaha. Dengan demikian hasil ini mendukung hipotesis. Hasil penelitian ini mendukung penelitian Wade et al. (2004), McGowan dan Durkin (2010) dan Doherty et al. (2016) yang menyimpulkan dengan mengadopsi teknologi internet menjadikan kegiatan bisnis lebih efisien dan menciptakan stategi bisnis yang baik sehingga meningkatkan kinerja usaha.

Penelitian ini membuktikan semakin meningkat penggunaan teknologi internet semakin mendorong meningkatnya kinerja usaha. Dengan mengadopsi teknologi 
internet yang digunakan sebagai alat komunikasi dan promosi pada pelanggan meningkatkan pertumbuhan pelanggan, dengan demikian penjualan dan keuntungan semakin meningkat. Hal tersebut akan meningkatkan modal usaha. Selain itu internet juga dapat digunakan dalam kegiatan bisnis lainnya seperti transaksi online dan kegiatan penjualan yang menciptakan efisiensi dalam operasional bisnis. Penerapan bisnis berbasis teknologi internet sejalan dengan fenomena penggunaan internet yang semakin tinggi dan telah menjadi gaya hidup manusia. Dengan demikian teknologi internet semakin mendekatkan dan memudahkan terjadinya transaksi penjualan. Semakin tinggi wirausaha menggunakan teknologi internet semakin lebih mudah memperoleh keberhasilan usaha.

\section{KESIMPULAN}

Penelitian ini bertujuan menguji secara mendalam hubungan dan pengaruh wirausaha berbasis teknologi internet terhadap kinerja UMKM di kota Tarakan. Hasil utama penelitian ini menyatakan bahwa penerapan bisnis berbasis teknologi internet dapat meningkatkan kinerja usaha. Dengan kata lain semakin meningkat wirausaha untuk mengadopsi dan menerapkan bisnis berbasis teknologi internet semakin meningkat kinerja usaha. Penelitian telah membuktikan bahwa teknologi internet berperan penting dalam meningkatkan kinerja usaha, maka wirausaha harus dapat mengintegrasikan kegiatan bisnisnya dan teknologi berbasis internet. Dengan demikian semakin membuka peluang dan memudahkan wirausaha atau UMKM dalam meningkatkan kinerja usaha melalui media internet.

Penelitian ini memiliki keterbatasan tidak memasukan variabel yang mempengaruhi wirausaha mengadopsi bisnis berbasis teknologi internet dalam model. Hasil penelitian membuktikan bahwa mengadopsi teknologi internet dalam kegiatan bisnis menjadi sangat penting karena menjadi penentu keberhasilan kinerja usaha. Maka perlu diketahui variabel apa saja yang mempengaruhi wirausaha menerapkan bisnis berbasis teknologi internet. Penelitian kedepan dapat memasukan dalam model variabel-variabel lainnya seperti kompetensi dan persaingan bisnis.

\section{REFERENSI}

APJII. 2016. Penetrasi dan Perilaku Pengguna Internet Indonesia (Survey 2016). In Polling Indonesia Asosiasi Penyelenggara Jasa Internet Indonesia.

BPS-Tarakan. 2017. Kota Tarakan dalam Angka 2017, edited by B. P. S. Tarakan.

Chaston, I., dan T. Mangles. 2003. "Relationship marketing in online business-tobusiness markets". European Journal of Marketing, Vol. 37, No. 5, hlm: 753 773. 
Datta, dan P. R. 2005. " Viral Marketing: New Form of Word-of-Mouth throug Internet". The Business Review, Vol. 3, No. 2.

Doherty, E., E. Ramsey, P. Harrigan, dan P. Ibbotson. 2016. "Impact of Broadband Internet Technologies on Business Performance of Irish SMEs". Strategic Change, Vol. 25, No., hlm: 693-716.

Ghozali, I. 2009. Aplikasi Analisis Multivariate dengan Program SPSS. Semarang: Badan Penerbit Universitas Diponegoro.

Kemkominfo. 2016. Laporan Kinerja 2016. Kementerian Komunikasi dan Informatika.

Kraus, S., J. P. C. Rigtering, M. Hughes, dan V. Hosman. 2012. "Entrepreneurial orientation and the business performance of SMEs: a quantitative study from the Netherlands". Review Managerial Science, Vol. 6, No. 2, hlm: 161-182.

McGowan, P., dan M. G. Durkin. 2010. "Toward an Understanding of Internet Adoption at the Marketing/Entrepreneurship Interface". Journal of Marketing Management, Vol. 18, No., hlm: 361-377.

Meutiaa, dan T. Ismail. 2012. "The Development of Entrepreneurial Social Competence And Business Network to Improve Competitive Advantage And Business Performance of Small Medium Sized Enterprises: A Case Study of Batik Industry In Indonesia". Procedia - Social and Behavioral Sciences, Vol. 65, No., hlm: 46 - 51.

Mujiyana, L. Sularto, dan M. A. Mukhyi. 2012. "Pengaruh Penerapan Periklanan DI Internet dan Pemasaran Melalui E-mail Produk UMKM dI Wilayah Depok". Jurnal TI Undip, Vol. VII, No. 3, hlm: 161-168.

Nunnaly, J. 1967. Psychometric Methods. NewYork: McGraw-Hill.

Papows, J. 1998. Enterprise.com: Reading, MA: Perseus Books.

Peterson, R. A., S. Balasubramanian, dan B. J. Bronnenberg. 1997. "Exploring the Implications of the Internet for Consumer Marketing". Journal of the Academy of Marketing Science, Vol. 25, No. 4, hlm: 329-346. 
Prasad, V. K., K. Ramamurthy, dan G. M. Naidu. 2001. "The Influence of InternetMarketing Integration on Marketing Competencies and Export Performance". Journal of International Marketing, Vol. 9, No. 4, hlm: 82-110.

Reimers, V., C. W. Chao, dan S. Gorman. 2016. "Permission email marketing and its influence on online shopping". Asia Pacific Journal of Marketing and Logistics, Vol. 28, No. 2, hlm: 308 -322.

Rosalind Jones, P. Alford, dan S. Wolfenden. 2015. Entrepreneurial Marketing in the Digital Age: A study of the SME tourism industry, edited by eprints.bournemouth.ac.uk.

Sidik, I. G. 2012 "Conceptual framework of factors affecting SME development: mediating factors on the relationship of entrepreneur traits and SME performance". Procedia Economics and Finance, Vol. 4, No., hlm: 373 - 383.

Soininen, J., M. Martikainen, Puumalainen, dan K. Kyläheiko. 2012. "Entrepreneurial orientation: Growth and profitability of Finnish small- and medium-sized enterprises". International Journal Production Economics, Vol. 140, No., hlm: 614-621.

Strauss, J., A. El-Ansary, dan R. Frost. 2003. E-Marketing. New York: Prentice Hall.

Sugiyono. 2012. Metode Penelitian Bisnis. Bandung: Alfabeta.

The-Economist. 1999. A Survey of Business and the Internet.

Venkatraman, N., dan V. Ramanujam. 1986. "Measurement of Business Performance in Strategy Research: A Comparison of Approaches". The Academy of Management Review, Vol. 11, No. 4, hlm: 801-814.

Wade, M., D. Johnston, dan R. McClean. 2004. "Exploring the net impact of internet business solution adoption on SME performance". International Journal of Electronic Business, Vol. 2, No. 4, hlm: 336-350. 